\title{
TEMPORAL-SPATIAL DISTRIBUTION CHARACTERISTICS AND ENVIRONMENTAL BACKGROUND OF MIDDLE HOLOCENE SETTLEMENTS ON THE SOUTH COAST OF LAIZHOU BAY, NORTHERN SHANDONG, CHINA
}

\author{
Zou, C. H. - ZHAO, Q. ${ }^{*}$ LI, X. M. - GaO, Q. \\ School of Water Conservancy and Environment, University of Jinan \\ Jinan 250022, Shandong Province, China \\ *Corresponding author \\ e-mail: stu_zhaoq@ujn.edu.cn; phone: +86-135-8910-8827 \\ (Received 29 $9^{\text {th }}$ Sep 2018; accepted $27^{\text {th }}$ Nov 2018)
}

\begin{abstract}
With increasing collaboration between archeology and natural sciences, the interactions between paleocultures and paleoenvironment have received more attention in recent years. In this investigation, the authors used nine radiocarbon dates from five profiles to explore the environmental evolution of the south coast of Laizhou Bay, and investigated the spatial-temporal distributions of archeological sites in the Middle Holocene as well as discussed the relationships between human cultures and environmental changes. The results show that the Neolithic archeological sites were mainly distributed in the flat (slopes $<4^{\circ}$ ) marine plain and alluvial plains with elevations below $29 \mathrm{~m}$, and the quantity and frequency of archeological sites exhibited an early ascending and later descending trend. Multiple data such as those of slope and extent close to the riverside were integrated to indicate that the ability of the ancients to adapt to the environment gradually increased. Further comparison revealed the correlation among Holocene climate change and environmental evolution and the Neolithic cultural development in the study area, which concerns the generally improved living conditions, the development of the primitive culture whereas degeneration coincided with the culture's transition or interruption. The results highlight the geographical factors in the development of prehistoric culture, especially the climatic factors.
\end{abstract}

Keywords: the south coast of Laizhou Bay, climate change, settlement distribution, sea level changes

\section{Introduction}

Past Global Changes (PAGES) focused on the coupling between prehistoric human socioeconomic activities and the natural environment. Therefore, the spatial and temporal distribution of archaeological sites and the response of human activities to Holocene climate change have become the central issue of current research on the human-land relationships. Currently, archeologists no longer discuss the rise and fall of civilizations from the perspective of cultural relics but gradually notice the influence of climate and natural environment changes on human activities (Karakasidou, 2005; Kuper and Kröpelin, 2006; Dong et al., 2013; Goude and Fontugne, 2016; Mayke et al., 2013). Since the 1980s, many scholars have used the interdisciplinary studies concerning sedimentary strata, sporopollen analysis and geology, geography and zoology to conduct research on the relationship between paleoenvironment and paleoculture, and they have achieved good research results (Wang et al., 2017; Li et al., 2010; Stanley and Galili, 1996). Research in the field of archeology pays more attention to analyzing the temporal and spatial changes of the distribution of sites and discusses the influence of terrain, landform, slope, sea level and other impact factors on the distribution of sites (Zheng et al., 2018; Demján and Dreslerová, 2016; Guo et al., 2014). Researches showed that prehistoric humans mostly chose terraces and platforms 
with superior ecological conditions and rich hydrothermal resources (Dai et al., 2016; An et al., 2015; Tan et al., 2015; Dong et al., 2013; Contreras et al., 2018; Lyndsay et al., 2018; Spencer and Bevan, 2018). However, due to the lack of high-resolution environmental archeological materials, how to precisely define regional human land interactions is remaining a challenging issue.

The Haidai cultural district is centered on the present-day Shandong Province and is among the important cultural lineages of Chinese civilization. In-depth systematic study of the spatial and temporal distribution of this regional archeological site and its environmental background for ancient human activities are of great significance for understanding the origins and processes of Chinese civilization and the interrelationship among environmental evolutions. During the last few decades, research on the climate and environmental evolution of the Neolithic Age in Haidai area has primarily focused on the change of coastline and vegetation in the local area (Yang et al., 2016). Meanwhile, on the basis of paleoclimate and environmental research, some scholars have focused on the impact of sea level fluctuations on paleoculture (Guo et al., 2014). However, those studies have significant imbalances in research areas and outcomes, as well as regional comparative studies and comprehensive analyses. This is not only a shortcoming in the study of paleoclimate and paleoenvironment but also has clearly influenced the understanding of the environmental background of archeological culture in the Neolithic Age. The southern coast of Laizhou Bay is one of the most typical areas of Neolithic cultural sites and is also among the key areas for studying the relationship between ancient cultural sites and environmental evolution. In the last few decades, some intensive research has been conducted on the south coast of Laizhou Bay on the basis of lacustrine-marine facies profile sedimentary information combined with Neolithic archeological data, and has implied the possible cultural impact of paleoclimate variation and the prehistorical human interactions during past global changes. Judian Lake, a lagoon formed by coastal depressions, is the largest ancient lake on the south coast of Laizhou Bay, and the lagoon evolved into a freshwater lake after the Huanghua transgression of the region. Therefore, it is of great significance to study the Judian Lake strata to reveal the paleogeographic environment along the coast of Laizhou Bay. In this study, we analyze the spatial and temporal characteristics of the 142 Neolithic cultural sites on the south coast of Laizhou Bay. Combining earlier reconstructed environmental records and using archeological data with our recent research and experiences, we are now able to delineate a comprehensive picture of the varieties and properties of the Neolithic culture along with the paleoclimatic, paleoenvironmental and paleoecological changes.

Based on the fieldwork, the authors selected two representative profiles in the study area to assist in exploring the features of the Holocene stratum deposition and the process of paleoenvironmental evolution in the study area. Accelerator Mass Spectrometry (AMS) radiocarbon dating methods were used to date samples from the Judian lake (Drilling name abbreviation: JDH) $\left(37^{\circ} 04^{\prime} 25.02^{\prime \prime} \mathrm{N}, 118^{\circ} 43^{\prime} 0.61 \mathrm{E}^{\prime \prime}\right.$ and $3.2 \mathrm{~m}$ altitude) and the town of Taitou (Drilling name abbreviation: TTZ) $\left(37^{\circ} 05^{\prime} 21.71^{\prime \prime} \mathrm{N}, 118^{\circ} 39^{\prime} 51.69 \mathrm{E}^{\prime \prime}\right.$ and $7.0 \mathrm{~m}$ altitude) profiles for constructing the timescale. All the dating samples were pretreated and measured at Beta dating laboratory in Miami, FL, USA. The Conventional Radiocarbon Ages have all been corrected for total fractionation effects and under the applicable circumstances, the calibration was performed by using 2013 calibration databases (referred to 'cal. BP'). As usual, conventional radiocarbon ages and sigmas are rounded up to the nearest 10 
years according to the 1977 International Conference on Radioactive Carbon practice. In addition, we also selected three other profile drills (Drilling name abbreviation: XHK, A1, SWC) in the area and obtained their dating data, which were used to reconstruct the time scale.

The information of 142 archeological sites was collected mainly from the Atlas of Chinese Cultural Relics: Shandong Section and other published documents. The chronology of these sites can be classified into four stages based on their cultural sequences and ${ }^{14} \mathrm{C}$ dating data: the HouLi Culture stage $(8.5 \sim 7.7$ cal.ka BP), the Dawenkou Culture stage (6.1 4.6 cal.ka BP), the Longshan Culture stage (4.6 4.0 cal.ka BP) and the Yueshi Culture stage (4.0 3.5 cal.ka BP) (Bureau of National Cultural Relics, 1997). The DEM (Digital Elevation Model) elevation data of the southern coast of Laizhou Bay were collected from the Geospatial Data Cloud website, and the SRTM4.1 DEM data set with a spatial resolution of $30 \times 30 \mathrm{~m}$ was also used in this study. Erdas Imagine 9.2 was used to synthesize 4 elevation data maps into a DEM map of the southern coast of Laizhou Bay, which was processed and vectorized in the ArcGIS 10.3 software environment. The ASTM DEM data of $30 \times 30 \mathrm{~m}$ horizontal resolution was superimposed with the cultural sites of different periods on the south coast of Laizhou Bay, and the cultural sites of different periods in the area were obtained. The altitudes of archeological sites were obtained by using the 'Extract Values to Points' tool for further analysis.

\section{Study area}

The southern coast of Laizhou Bay locates in the north-central region of Shandong Province, China. It covers most of Laizhou County and parts of Guangrao, Shouguang, Changyi and Hanting Counties (Fig. 1).

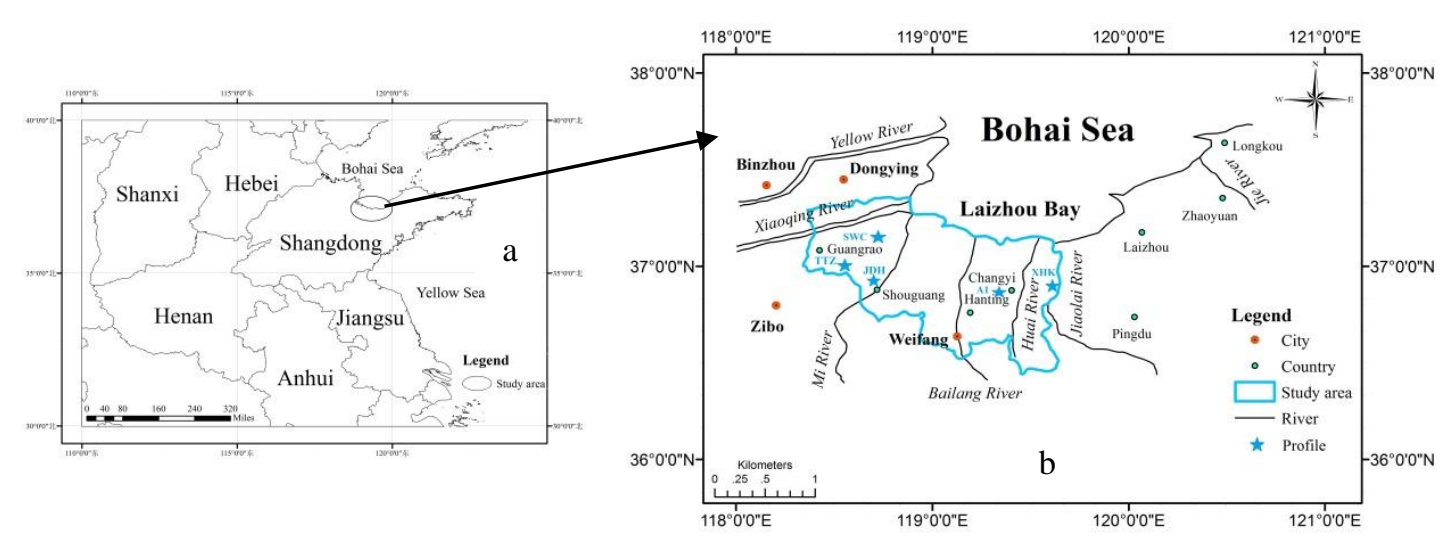

Figure 1. (a) Maps of northern China and surrounding regions showing provincial boundaries and location of Laizhou Bay; (b) geographic sketch of Laizhou Bay and the locations of profiles and sites mentioned in the current study

From the south to the north, the topography of the study area is transformed from aggraded flood plain to alluvial plain, whereas to the Laizhou Bay coast is narrow banded alluvial plain and marine plain. The south coast of the Laizhou Bay exhibits warm temperate continental monsoon climate characterized by warm humid summers and cool, dry winters. The annual average temperature of the study area is $12.2{ }^{\circ} \mathrm{C}$, and 
the annual average precipitation is $559.5 \mathrm{~mm}$, mainly concentrated in spring and summer. Many short-source rivers (mainly the Xiaoqing River, Mi River, Bailang River, Huai River, Jiaolai River and their branches) constitute an intricate water network in the region.

\section{Results}

\section{Dating results}

The dating results of nine samples collected from the XHK (Han and Zhang, 2005), the A1 (Liu et al., 2004), the SWC (Guo et al., 2013), the JDH and the TTZ profiles in the study area are shown in Table 1. A total of nine radiocarbon dates were obtained and the ages are in stratigraphic order.

Table 1. AMS $-{ }^{14} C$ ages of the XHK, Al, SWC, JDH and TTZ profiles

\begin{tabular}{c|c|c|c|c|c}
\hline $\begin{array}{c}\text { Laboratory } \\
\text { original code }\end{array}$ & Depth $(\mathbf{m})$ & $\begin{array}{c}\text { Dating } \\
\text { method }\end{array}$ & Dating material & Age (cal.ka BP) & Profile \\
\hline XHK $(4-9 \mathrm{~m})$ & $4-9$ & AMS- $-{ }^{14} \mathrm{C}$ & Clayey silt & $5.530 \pm 0.14$ & XHK \\
A1-4 & 4.5 & AMS $-{ }^{14} \mathrm{C}$ & Clayey silt & $5.383 \pm 0.064$ & A1 \\
A1-7 & 7.6 & AMS $-{ }^{14} \mathrm{C}$ & Clayey silt & $9.826 \pm 0.075$ & A1 \\
SWC-W1 & $0.75-1$ & AMS- ${ }^{14} \mathrm{C}$ & Clayey silt & $5.510 \pm 0.07$ & SWC \\
SWC-W2 & $2.25-2.5$ & AMS $-{ }^{14} \mathrm{C}$ & Clayey silt & $6.350 \pm 0.045$ & SWC \\
JDH65 & $1.29-1.3$ & AMS $-{ }^{14} \mathrm{C}$ & Peat & $5.240 \pm 0.03$ & JDH \\
JDH135 & $2.69-2.70$ & AMS- ${ }^{14} \mathrm{C}$ & Peat & $5.990 \pm 0.03$ & JDH \\
JDH192 & $3.83-3.84$ & AMS $-{ }^{14} \mathrm{C}$ & Peat & $6.900 \pm 0.03$ & JDH \\
TTZ & $1.61-1.62$ & AMS- $-{ }^{14} \mathrm{C}$ & Peat & $6.510 \pm 0.03$ & TTZ \\
\hline
\end{tabular}

\section{Number and elevations of archeological sites}

The total number of archeological sites on the southern coast of Laizhou Bay throughout the Neolithic Age is listed in Table 2, which shows an early ascending curve and an later descending curve from the 3 Houli sites up to the 27 Dawenkou sites, and an increase to the 101 Longshan sites and finally the 57 sites of the late period of the Yueshi culture. The occurrence frequency of these sites in each period slowly grew from $0.38 / 100$ a to $1.8 / 100$ a, dramatically increased to $16.83 / 100 a$, finally fell to only 2.2/100a (Table 2). Accompanied by cultural evolution, the distribution and types of archeological sites in different cultural stages have different changes. In Houli culture stage, the sites have a mostly scattered distribution, and all sites are located on the proluvial platform or alluvial plains near river banks. Different from the previous cultural stage, the sites from the Dawenkou cultural stage mostly appear farther from the river bank and at lower elevations, for example, Wucun, Fujia and Rongzhuang. During the Longshan culture period, the distribution was further expanded. In the western region, there is a trend of a concentrated distribution of dual centers, and the eastern decentralization trend is obvious. It is worth mentioning that a lower elevation archeological site (the Guojingzi site) appeared in the study area during this cultural period, which was the first site found in the northern marine plain. Although the number 
of sites in the Yueshi culture stage has decreased significantly, the distribution of landform type and its trend did not change much, and are similar to the previous period.

Table 2. Neolithic cultural sequence and content on the south coast of Laizhou Bay

\begin{tabular}{c|c|c|c}
\hline $\begin{array}{c}\text { Archeological } \\
\text { culture sequence }\end{array}$ & $\begin{array}{c}{ }^{14} \mathbf{C} \text { age } \\
\text { (ka BP) }\end{array}$ & Typical sites and contents & $\begin{array}{c}\text { Amount/occurrence } \\
\text { frequency of the } \\
\text { archeological sites (/100a) }\end{array}$ \\
\hline Houli Culture & cal. 8.5-7.7 & $\begin{array}{c}\text { Qianbuxia, Lujiakou and } \\
\text { Bianxianwangxi }\end{array}$ & $3 / 0.38$ \\
\hline Dawenkou Culture & cal. 6.1-4.6 & $\begin{array}{c}\text { Rongzhuang, Dongjia, Wucun, } \\
\text { Qianbuxia, and Fujia }\end{array}$ & $27 / 1.8$ \\
\hline Longshan Culture & cal. 4.6-4.0 & Lujiakou, Guojingzi and Zhongjia & $101 / 16.83$ \\
\hline Yueshi Culture & cal. 4.0-3.5 & Xidu and Zhongjia & $11 / 2.2$ \\
\hline
\end{tabular}

In the study area, the altitudes of the archeological sites are relatively low, and up to $75 \%$ of the sites are distributed in areas below $29 \mathrm{~m}$ asl (Table 3). All three Houli culture sites are concentrated in areas with elevations below $39 \mathrm{~m}$ asl, and two-thirds of them are distributed in areas with elevations of 10-19 $\mathrm{m}$ asl (Fig. 2a).

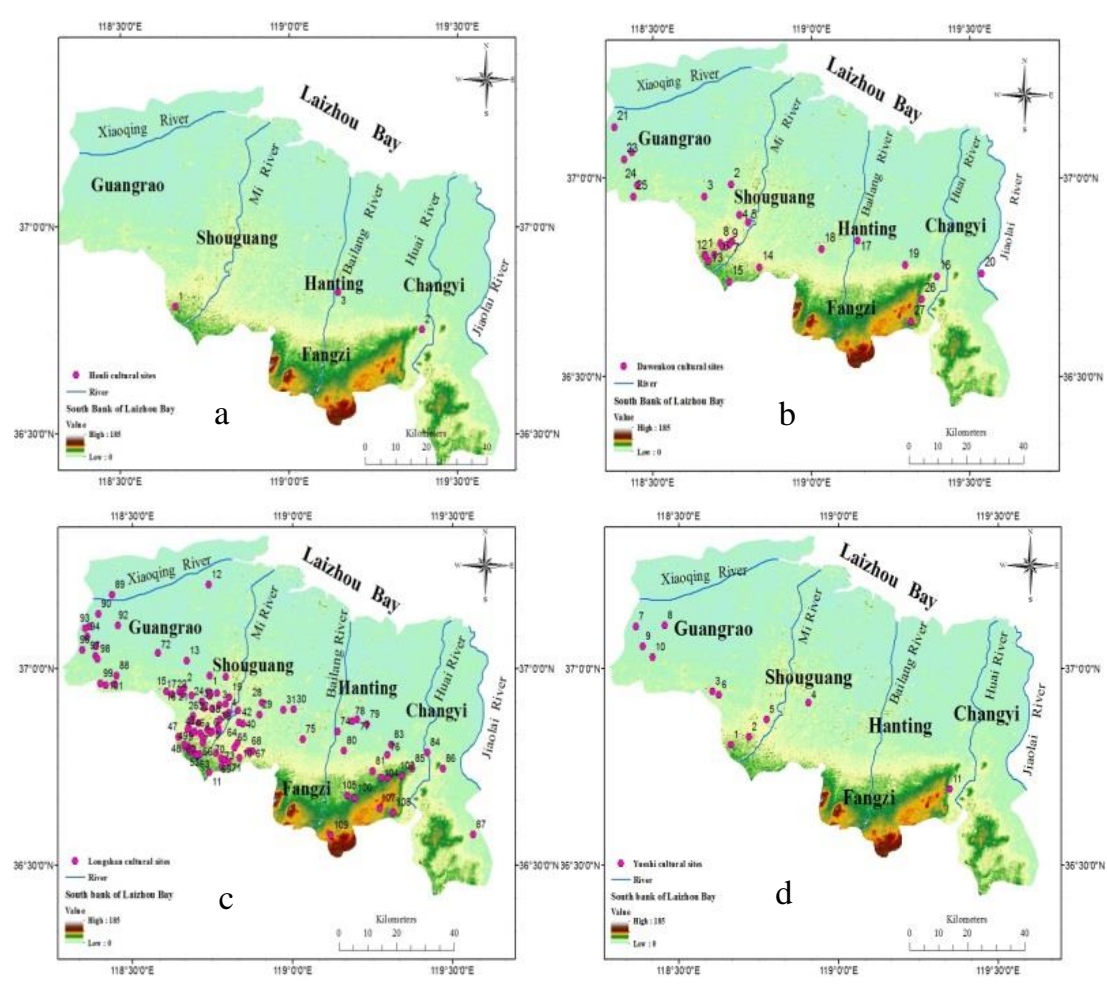

Figure 2. Distribution of archeological sites on the south coast of Laizhou Bay. (a) Houli cultural stage; (b) Dawenkou cultural stage; (c) Longshan cultural stage; (d) Yueshi cultural stage

The number of sites of the Dawenkou culture increases to 27 , and the distribution in this stage moves towards high-lying plain with 6 sites above $29 \mathrm{~m}$ asl, which represents $22.2 \%$ of all the sites of the period (Fig. 2b). During the Longshan cultural stage, the 
development of Neolithic Culture accelerated on the southern coast of Laizhou Bay. The number of sites dramatically increased to 101 and their distribution expanded markedly around river banks (Fig. 2c). The percentage of sites above $29 \mathrm{~m}$ asl increased by $5.5 \%$ from the previous period, but $72.3 \%$ of the sites remained in plains with elevations below $29 \mathrm{~m}$ asl (Table 3). However, the growing trend in the number of sites was interrupted by a striking decline, and the type of site and spatial agglomeration were greatly reduced in the late Longshan cultural period $(\sim 4.0$ cal.ka BP). Subsequently, the Yueshi Culture began to develop, but the quantity, scope and distribution density were far less than the previous three cultural stages. There are 9 sites distributed in areas below $29 \mathrm{~m}$ asl, which account for $81.2 \%$ of all the sites of the Yueshi culture (Fig. 2d).

Table 3. The altitude distribution of the Neolithic cultural sites on the south coast of Laizhou Bay

\begin{tabular}{c|c|c|c|c|c}
\hline \multirow{2}{*}{ Classification } & \multicolumn{4}{|c|}{ Distribution with different altitude } & \multirow{2}{*}{ Total } \\
\cline { 2 - 5 } & $<\mathbf{1 0 m}$ asl & $\mathbf{1 0 - 1 9 m}$ asl & $\mathbf{2 0 - 2 9 m}$ asl & $\mathbf{>}$ 29m asl & \\
\hline Houli & 00 & $266.67 \%$ & 00 & $133.33 \%$ & 3 \\
Dawenkou & $27.41 \%$ & $1244.44 \%$ & $725.93 \%$ & $622.22 \%$ & 27 \\
Longshan & $1716.83 \%$ & $3231.68 \%$ & $2423.76 \%$ & $2827.72 \%$ & 101 \\
Yueshi & $436.36 \%$ & $327.27 \%$ & $218.18 \%$ & $218.18 \%$ & 11 \\
\hline
\end{tabular}

\section{Slope and aspect}

The archeological sites of the Houli Culture period are all distributed in an area with a gentle gradient of $2 \sim 4^{\circ}$, but there are only three archeological sites for that period and therefore it has no statistical significance. During the Dawenkou Culture period, the archeological sites were mainly distributed in the flat areas with slopes ranging from 0 to $4^{\circ}$, and the cumulative proportion is approximately $89 \%$ of the same period. In the gentle slope areas with slopes ranging from 0 to $6^{\circ}$, the distribution of archeological sites shows a trend of decreasing with increasing slope. However, in the $6 \sim 8^{\circ}$ area, the number of archeological sites is relatively increased, and there are no archaeological sites in the areas above $8^{\circ}$. For the Longshan Culture stage, the archeological sites are also mainly distributed in flat areas with slopes ranging from 0 to $4^{\circ}$, and the cumulative proportion is approximately $86 \%$ of the same period. Settlement sites occur within the entire slope distribution, and the number decreases as the slope increases. The distribution trend of archeological sites during the Yueshi period is basically the same as that of the Dawenkou period. The archeological sites are mainly distributed in flat areas with slopes ranging from 0 to $4^{\circ}$, and the cumulative proportion is approximately $91 \%$ of the same period. In places with gentle slopes of $0 \sim 4^{\circ}$, the distribution of archeological sites shows a trend of decreasing with increasing slopes, but in 6-8 $8^{\circ}$ areas, there is a relative increase in the number of archeological sites, and there are no settlements in areas above $8^{\circ}$ (Fig. 3).

Viewed from the aspect of archaeological sites, the ancients usually lived on relatively warm aspects such as south, southeast, and southwest aspects, and very few humans lived in the northern aspect. On the habitable aspect, there are fifteen Dawenkou cultural archaeological sites, with a proportion of $55.6 \%$, and 63 archaeological sites from the Longshan Culture period, with a proportion of $62.3 \%$, as 
well as 6 archeological sites from the Yueshi Culture period, with a proportion of 54.5\%. Among them, the archeological sites from the Longshan Culture period are distributed over various aspects, indicating that the population of the ancients grew on a large scale and their ability to adapt to the environment was enhanced.

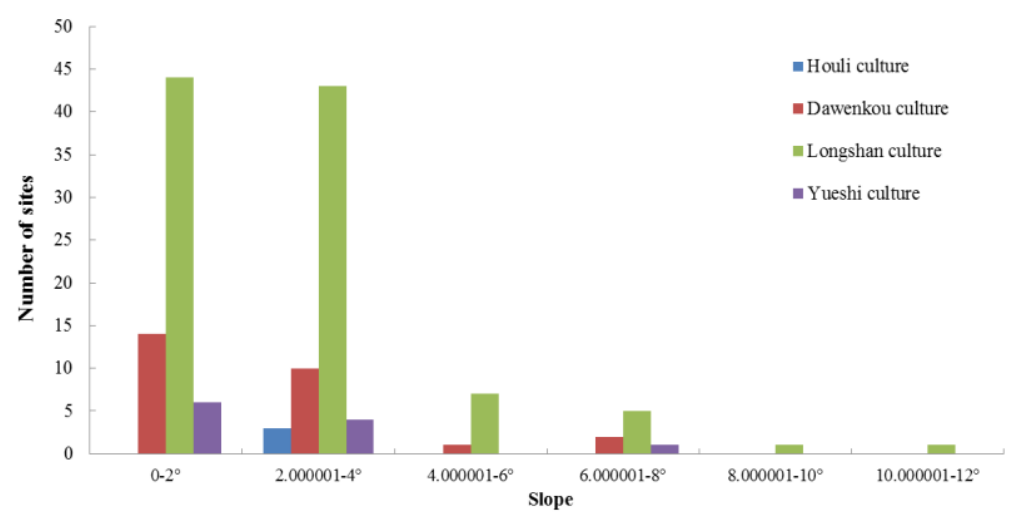

Figure 3. Slope distribution of the middle Holocene archaeological sites

\section{The extent close to riverside}

The extent close to riverside reflects the use of water by the ancients. In this investigation, the authors used ArcGIS to establish three river buffer zones of $0-1 \mathrm{~km}$, $1-2 \mathrm{~km}$ and 2-3 $\mathrm{km}$ based on the present location of the rivers. By calculating the percentage of sites covered by different buffer zones, we can analyze the extent close to riverside of different cultural stages. Somewhat in parallel, the buffer distance $1 \mathrm{~km}$ and $3 \mathrm{~km}$ showed an overall descending trend for the coverage of the four periods. Figure 5 lists the coverage by means of proximity analysis and buffer analysis in ArcToolbox. For instance, for the Houli Culture stage, the maximum $1 \mathrm{~km}$ coverage is approximately $33.3 \%$, which triples that of the approximately $11.1 \%$ for the Dawenkou stage; however, it is merely approximately $9.9 \%$ for the Longshan stage and $0 \%$ for the Yueshi stage. Similarly, the $3 \mathrm{~km}$ coverage in the first three cultural stages changed from $66.7 \%$ to $37 \%$ and then $26.7 \%$. Although it rose slightly during the Yueshi Culture stage $(27.3 \%)$, the decline was still larger than that of the previous two cultural stages. From the Houli Culture stage to the Longshan Culture stage, the $1 \mathrm{~km}$ and $3 \mathrm{~km}$ site coverages were reduced in comparison with the previous period, and the reduction of the four stages were $22.2 \%, 29.7 \%, 1.2 \%$ and $10.3 \%$, respectively (Fig. 4). These results demonstrate that the influence of rivers on the selection of archeological sites has gradually decreased, and the ability of the ancients to adapt to the environment had gradually increased. Due to the small watershed area and limited hydrodynamic forces, the rate of undercutting of rivers is very slow. Therefore, the influence of river undercut on the extent close to riversides is not taken into consideration in this investigation.

\section{Discussion}

\section{Environmental changes on the south coast of Laizhou Bay}

For the typical continuous natural sedimentary profiles in the same study area, the soil layers at different depths contain information about the evolution of the natural 
environment background at different periods. Therefore, analyzing the sedimentary types of soil layers at different depths and combining them with the spatial and temporal distribution characteristics of the sites can help reveal the connection between human civilization development and environmental evolution. According to field surveys and comparative studies concerning strata of typical profiles (Fig. 5), marine deposit and fluvial facies sedimentation occurred on the south coast of Laizhou Bay in the Middle Holocene. The sedimentary lithology can be divided into four layers from top to bottom, and the lithological characteristics of this area are not significantly different (Table 4).

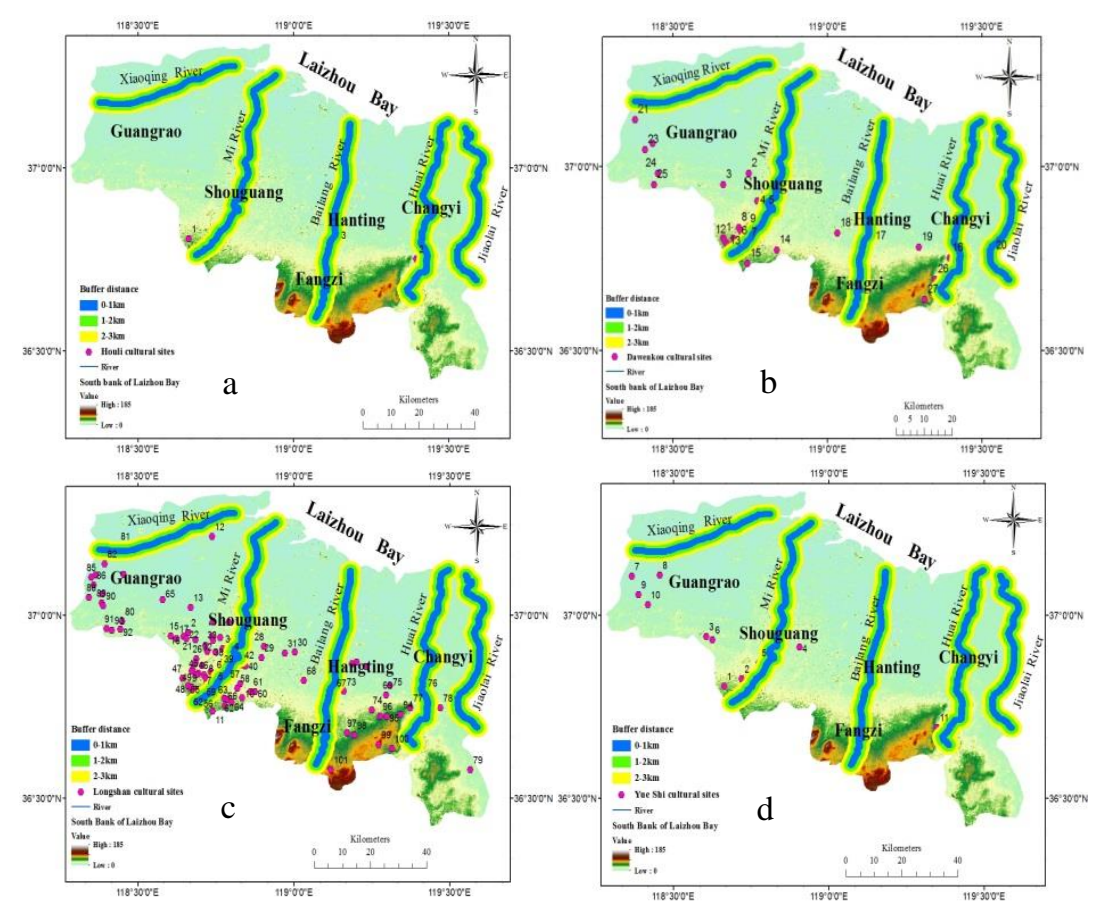

Figure 4. Buffer distance of archeological sites on the south coast of Laizhou Bay. (a) Houli cultural stage; (b) Dawenkou cultural stage; (c) Longshan cultural stage; (d) Yueshi cultural stage
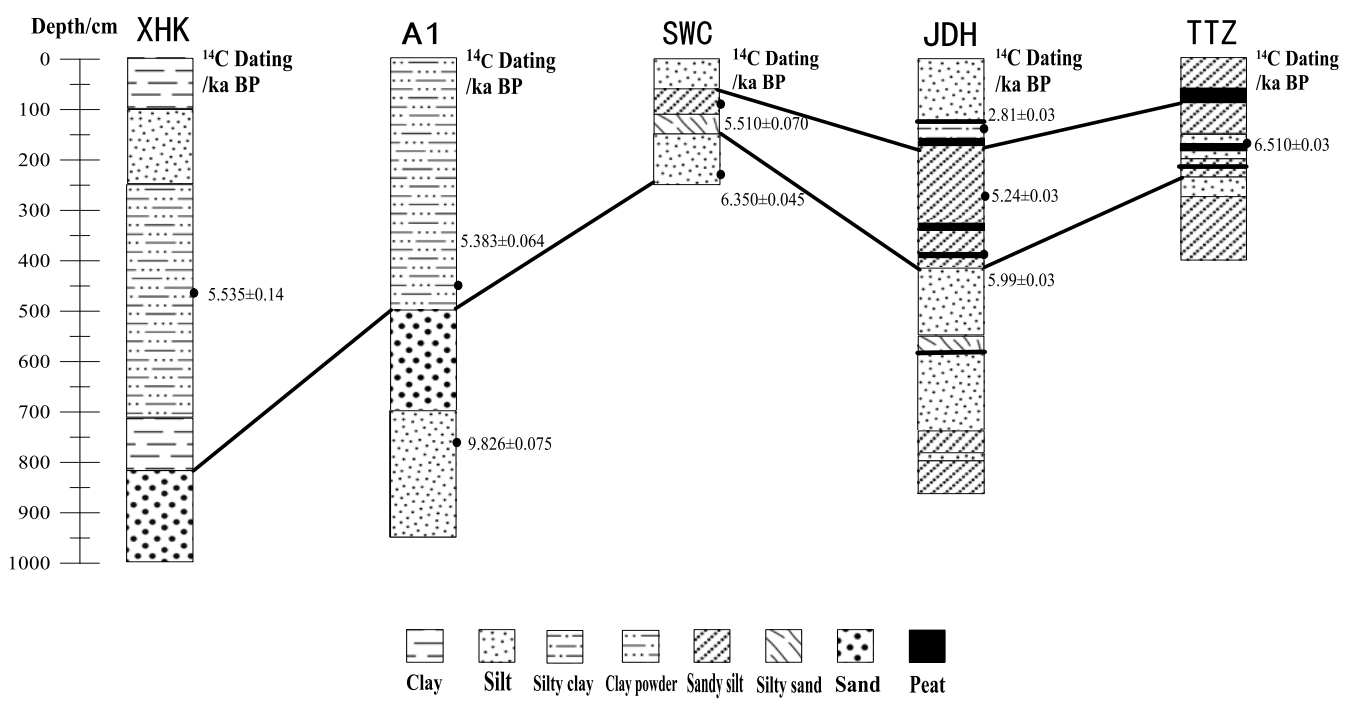

Figure 5. Stratigraphic correlation of typical profiles of the south coast of Laizhou Bay 
Table 4. Vertical depositional sequence of sedimentary strata in Judian Lake

\begin{tabular}{|c|c|c|c|c|c|c|c|}
\hline \multirow{2}{*}{ Lithology } & \multirow{2}{*}{$\begin{array}{c}\text { Buried } \\
\text { depth }(\mathrm{m})\end{array}$} & \multirow{2}{*}{ Sedimentary characteristics } & \multicolumn{4}{|c|}{ Particle-size parameters } & \multirow{2}{*}{$\begin{array}{c}\text { Age } \\
(\text { cal.ka BP })\end{array}$} \\
\hline & & & $\mathbf{M z}_{\mathrm{z}}$ & KG & SK & QDe & \\
\hline $\begin{array}{l}\text { I. Clay silt } \\
\text { and silty } \\
\text { clay }\end{array}$ & $0 \sim 0.9$ & $\begin{array}{c}\text { The cracks are relatively developed, a } \\
\text { large number of plant roots and } \\
\text { visible tiny wormholes are } \\
\text { sandwiched, and a thin layer of silt is } \\
\text { partially attached with mud } \\
\text { distribution }\end{array}$ & $5.0-8.3$ & $0.76-1.5$ & $-0.1-0.6$ & $1.5-3.0$ & \\
\hline $\begin{array}{l}\text { II. Silty } \\
\text { sand, } \\
\text { sandy silt } \\
\text { and silt }\end{array}$ & $0.9 \sim 2.5$ & \begin{tabular}{|} 
The color of the upper part is \\
yellowish brown - brown-gray, \\
which occasionally encloses sporadic \\
shells (shell debris), wormholes and \\
plant debris, and the water content is \\
saturated; the lower part is gray- \\
grayish green-grayish black, \\
containing a mud silty clay layer with \\
a high moisture content and a \\
saturated shape
\end{tabular} & $5.1-6.6$ & $0.78-1.54$ & $-0.1-0.6$ & $0.5-1.0$ & $2.81 \pm 0.03$ \\
\hline $\begin{array}{l}\text { III. Clay } \\
\text { silt and } \\
\text { silty clay }\end{array}$ & $2.5 \sim 4.0$ & $\begin{array}{l}\text { The color distribution is horizontally } \\
\text { layered, the color changes to gray- } \\
\text { grayish green-grayish black, and is } \\
\text { rich in organic matter, decaying plant } \\
\text { roots, mud and shell debris. The } \\
\text { layers are discontinuously distributed } \\
\text { with clay silt and silty clay, with } \\
\text { brown peat and black clay locally }\end{array}$ & $5.1-6.7$ & $0.74-1.07$ & $0.1-0.6$ & $1.5-2.5$ & $5.24 \pm 0.03$ \\
\hline $\begin{array}{l}\text { IV. Silty } \\
\text { sand, } \\
\text { sandy silt } \\
\text { and silty }\end{array}$ & $4.0 \sim 8.6$ & $\begin{array}{c}\text { The color change is yellowish brown- } \\
\text { gray-dark gray, and the cracks are } \\
\text { relatively developed. The layer } \\
\text { generally contains white shells or } \\
\text { shell debris, and is concentrated in } \\
\text { the lower part }\end{array}$ & $5.4-7.0$ & $0.74-1.16$ & $-0.1-0.6$ & $1.0-1.5$ & $5.99 \pm 0.03$ \\
\hline
\end{tabular}

By comparison with the TTZ stratum, combined with the results of the XHK, SWC and A1 holes, the Holocene sedimentary facies in the Judian Lake area can be catagorized as follows.

(1) The I and II layers in the sedimentary sequence are the Holocene upper continental layers, and they are primarily composed of fluvial facies and lacustrine facies deposits. Layer I and the upper part of layer II are mainly fluvial facies deposits, and the lower part of layer II is mainly lacustrine facies deposits. From the perspective of granularity analysis, the quartile deviation $\left(\mathrm{QD}^{\varphi}\right)$ value is between 0.5 and 1.0, indicating that the sorting is good to very good; the average grain diameter (MZ) is 5.0 8.3 in a clay - very fine sand - fine silt, and the skewness (SK1), which is between -0.1 and 0.6 , is a very positive deviation, and the kurtosis (KG) is between 1.11 and 1.56, which is a narrow kurtosis. The peat layer was subjected to $\mathrm{AMS}^{14} \mathrm{C}$ dating, and its age is $2.81 \pm 0.03$ cal. ka BP. Combined with the lithology analysis of Table 4, the sedimentary phase of the I and II layers can be identified as fluvial facies and lacustrine facies deposits according to the lithologic characteristics of sediments and good sorting properties.

(2) The III layer is the marine layer of the Holocene, which is primarily comprised of the lagoon-shallow marine facies. By analyzing the sedimentary strata of JDH, it can be found that there are thick gray, grayish green or grayish black silty clay deposits with a depth of $2.6 \mathrm{~m}-3.3 \mathrm{~m}$ in layer III. Its texture is homogeneous, with horizontal bedding 
and light-colored reticulation. It contains more mollusk shells and shell clasts, and has the same sedimentary characteristics as Holocene marine facies. The AMS ${ }^{14} \mathrm{C}$ age of the peat-containing silty clay in the III layer was determined to be $5.24 \pm 0.03$ cal.ka BP. Meanwhile, the grain size analysis shows that the MZ value ranges from 5.1 to6.7, belonging to fine silt to ultrafine silt, and the peak state is wide to very wide, the sorting degree is medium-poor, the deviation is positive to extreme positive (Table 4). The sediments have extreme kurtosis values, indicating that the sedimentary environment is shallow-lagoon sedimentary environment due to the hydrodynamic conditions of shallow sea and lagoon environment, and the sorting efficiency is poor. The sediments in this area were in a beach environment with good hydrodynamic conditions in the early stage. Combined with the characteristics of the lithologic characteristics and grain size parameters, it can be concluded that the III layer are lagoon-shallow marine facies deposits.

(3) The IV layer is beach shore facies sedimentary environment. The sediments in this layer have normal skewness and peak state values, and the shape of the frequency curve has an almost single peak symmetry (Table 4). The grayish-black silt-bearing silty clay was subjected to $\mathrm{AMS}^{14} \mathrm{C}$ dating, and its age is $5.99 \pm 0.03$ cal.ka BP. Compared with the sediments in the third layer, the sorting degree, which is good to medium, becomes better. Because of the strong wave action and reciprocating motion in the beach-shore environment, the sediments are transported and sorted many times, and the fine clay particles are transported far from the shore, resulting in the better sorting degree. The comprehensive analysis of lithological characteristics and grain size characteristics indicates that the beach was in a beach shore sedimentary environment. According to the above-mentioned analysis, the Judian Lake depositional area was a beach-shore facies depositional environment at $5.99 \pm 0.03$ cal.ka BP, a lagoon-shallow facies depositional environment at $5.24 \pm 0.03$ cal.ka BP, as well as a continental fluvial facies and lacustrine facies depositional environment at $2.81 \pm 0.03$ cal.ka BP.

It is generally known that sporopollen are also among the most effective indicators of climate change. Han identified and analyzed the spores and pollens from the profile in Judian Lake sediment area. She found that herbaceous pollens accounted for the absolute predominance, the content was more than $85 \%$. Woody pollens were less than $15 \%$, and there were very few fern spores, the content of which was below $1 \%$ (Han and Zhang, 2005). From the Middle Holocene to the Late Holocene, the pollen content of Quercus in woody plants was high, and the pollen content of aquatic plants and hydrophytic plants varies from high to low, indicating that the climate shifted from humid to drought at that time. Based on the above-mentioned classification of sedimentary facies, the regularity on the climatic and environmental changes on the south coast of Laizhou Bay from the Middle Holocene to Late Holocene can be summarized as warm and partial wetting environment (early period of the Middle Holocene) - warm and humid environment (late period of the Middle Holocene) - warm and dry environment (late period of the Holocene).

There were also several climate fluctuation events along with the climate change on the southern coast of Laizhou Bay during the Middle Holocene, such as the 7.0 ka BP, $5.5 \mathrm{ka} \mathrm{BP}, 4.0 \mathrm{ka} \mathrm{BP}$ cooling events. The $\delta^{18} \mathrm{O}$ record of Dongge Cave demonstrated the continual increase in monsoon precipitation between 7.2 and $6.0 \mathrm{ka}$ (Dykoski et al., 2005; Fig. 6a). Pollen analysis of Judian lake confirmed decreasing temperatures by the relatively increasing concentrations of Pinus pollen. Figure $6 d$ shows significant cooling at approximately $7.0 \mathrm{ka}$, which coincided with the wide and shallow cold valley 
recorded in the $\delta^{18} \mathrm{O}$ Dunde ice core curve (Yao and Shi, 1992; Fig. 6c). At approximately $5.0 \mathrm{ka}$, the average $\delta^{18} \mathrm{O}$ values of stalagmites were relatively high despite some fluctuations, indicating a period of decreasing monsoon precipitation during the Middle Holocene (Andersen et al., 2004; Fig. 6a, b). The sporopollen data for the southern coast of Laizhou Bay showed that the forest coverage decreased sharply, while the grassland area expanded, and the forest vegetation was dominated by pine, revealing the climate experienced cooling fluctuation. After $5.0 \mathrm{ka}, \delta^{18} \mathrm{O}$ shifted towards greater values, indicating a decreasing trend in Asian monsoon intensity in the Mid-Late Holocene. This trend became even more prominent at approximately $4.0 \mathrm{ka}$ (Fig. 6a, b). The sporopollen records of this cooling event in the northern Shandong plain showed that the content of algae and ferns increased sharply in the sporopollen pattern, indicating the enlargement of the lake and marsh area. Previous studies have suggested that a flood event occurred in the middle and lower reaches of the Yellow River at approximately $4.0 \mathrm{ka} \mathrm{BP}$, which may caused the south coast of Laizhou Bay once again covered by lakes and marshes, and the aquatic and hydrophytic plants flourished.

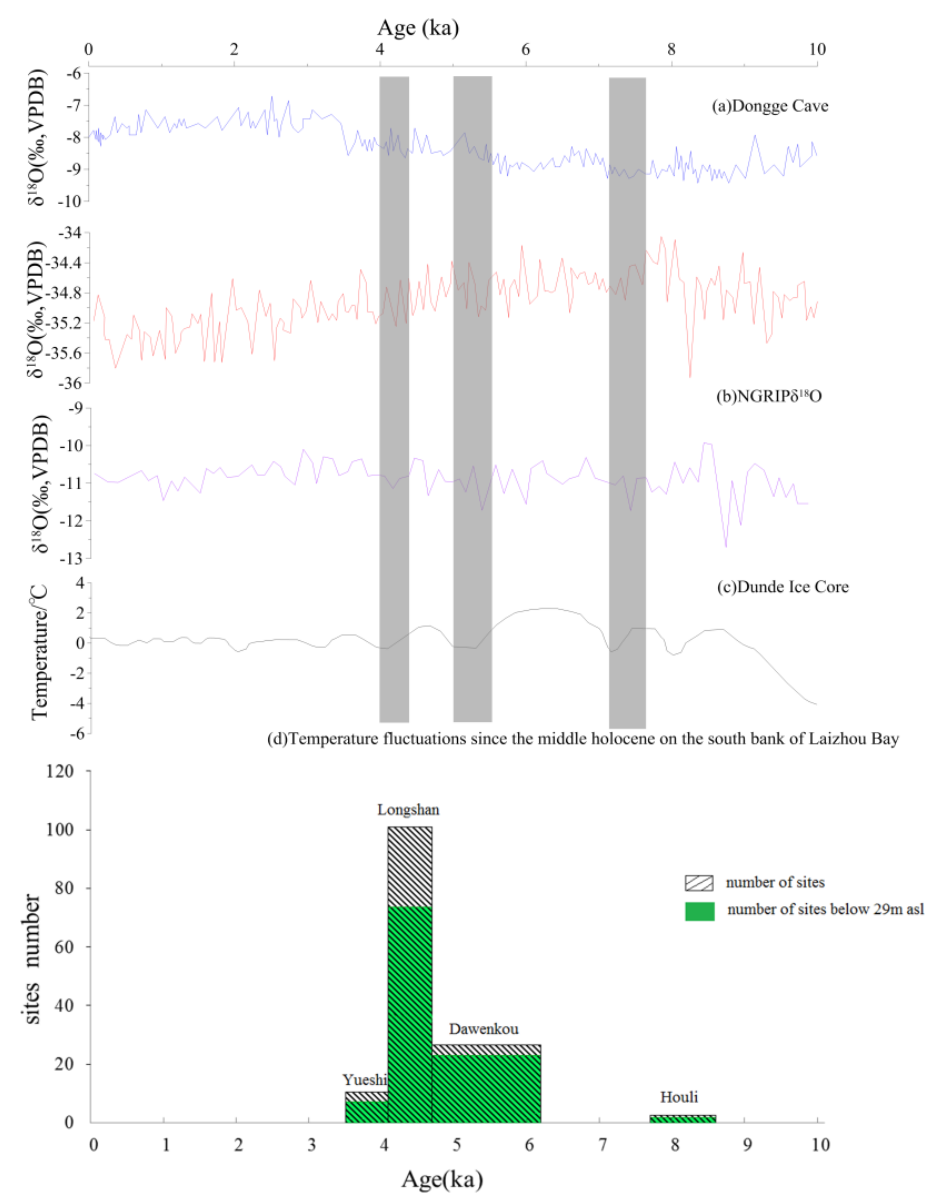

Figure 6. Comparisons between climate records and human settlements in the south coast of Laizhou Bay. (a) The $\delta^{18}$ O values of stalagmite from Dongge Cave (Dykoski et al., 2005); (b) $\delta^{18} \mathrm{O}$ values from the NGRIP Ice Core (Andersen et al., 2004); (c) $\delta^{18} \mathrm{O}$ values from the Dunde Ice Core (Yao and Shi, 1992); (d) The temperature fluctuation curve since the Middle

Holocene; (e) Total number of sites and number of sites below $29 \mathrm{~m}$ asl on the south coast of

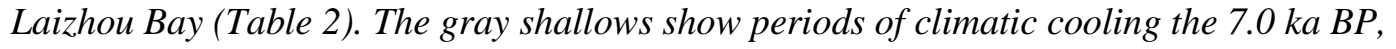




\section{Impacts of environmental changes on the development of cultures}

The existence and development of prehistoric culture depend on a certain natural environment. The remains of animals and plants found at the settlement sites reflect the influence of the climate environment on the development of prehistoric human culture. Therefore, the representative sites of different cultural stages are selected to summarize the climate and environmental information. Table 5 shows the corresponding information of the settlement sites on the south coast of Laizhou Bay and paleoenvironment.

Table 5. Correspondence between archeological sites and paleoenvironment on the south coast of Laizhou Bay

\begin{tabular}{|c|c|c|c|}
\hline $\begin{array}{c}\text { Cultural } \\
\text { period }\end{array}$ & Sites & Environmental information & Sources \\
\hline $\begin{array}{l}\text { Houli } \\
\text { Culture }\end{array}$ & $\begin{array}{l}\text { Qianbuxia } \\
\text { sites }\end{array}$ & $\begin{array}{l}1 \text { The growth of a large number of suitable plants near } \\
\text { the ruins of a warm and humid environment; } 2 \\
\text { Lamprotula, blue clams and other animal remains are } \\
\text { reflected near the Qianbuxia ruins of the forest } \\
\text { meadow environment; } 3 \text { Suitable climatic conditions, } \\
\text { mild and humid; } 4 \text { Fishing and hunting activities of } \\
\text { ancestors in the riverfront near the sea }\end{array}$ & $\begin{array}{c}\text { (Han and Wu, 1982; } \\
\text { Wang and Ning, } \\
\text { 2003) }\end{array}$ \\
\hline \multirow{3}{*}{$\begin{array}{l}\text { Dawenkou } \\
\text { Culture }\end{array}$} & $\begin{array}{l}\text { Qianbuxia } \\
\text { sites }\end{array}$ & $\begin{array}{l}1 \text { Increase in dry and cold climate plant specimens and } \\
\text { reduction in the wet and warm climate plant } \\
\text { specimens; } 2 \text { There are numerous aquatic plants and } \\
\text { reeds, which indicates that there were abundant water } \\
\text { resources }\end{array}$ & (Kong, 2000) \\
\hline & $\begin{array}{l}\text { Wucun } \\
\text { sites }\end{array}$ & $\begin{array}{c}\text { According to the survey, the average annual } \\
\text { temperature was } 2 \sim 4 \text { degrees higher than at present, } \\
\text { which was suitable for farmers engaged in farming and } \\
\text { fishing }\end{array}$ & (Jin, 2000) \\
\hline & $\begin{array}{l}\text { Fujia } \\
\text { sites }\end{array}$ & $\begin{array}{l}1 \text { The surface of the site is covered by a yellow soil, } \\
\text { and the cultural layer is red-brown or gray-brown; } 2 \\
\text { The ruins are distributed around the } 30-140 \mathrm{~m} \text { wide } \\
\text { puddles of water, suggesting an early drought climate } \\
\text { and subsequent humid climate, during which } \\
\text { numerous water puddles formed over a long period, } \\
\text { residents living in highlands; } 3 \text { Millet belonging to the } \\
\text { millet agriculture appeared in the ruins }\end{array}$ & (Kong, 1989) \\
\hline \multirow{2}{*}{$\begin{array}{l}\text { Longshan } \\
\text { Culture }\end{array}$} & $\begin{array}{l}\text { Lujiakou } \\
\text { sites }\end{array}$ & $\begin{array}{l}1 \text { Located on the South Coast of the Laizhou Bay } \\
\text { lowland alluvial plain; } 2 \text { Fishing activities in the } \\
\text { economic life held a certain degree of importance but } \\
\text { only in the scope of the river and estuary mouth } \\
\text { activities and not in deep ocean operations }\end{array}$ & $\begin{array}{c}\text { (Li et al., 2002; Han, } \\
1985)\end{array}$ \\
\hline & $\begin{array}{l}\text { Guojingzi } \\
\text { sites }\end{array}$ & $\begin{array}{c}1 \text { The Guojingzi site is located in a shell coast, the } \\
\text { shell }{ }^{14} \mathrm{C} \text { dating is } 5.0 \text { cal.ka.BP.; } 2 \text { The ruins contain } \\
\text { large amounts of plant ash, burned soil and white } \\
\text { lumps; } 3 \text { There is a small number of hair clams, the } \\
\text { remains of which reflect a beach tcoastline } \\
\text { sedimentary environment }\end{array}$ & $\begin{array}{c}\text { (Li et al., 1996; He, } \\
\text { 2004) }\end{array}$ \\
\hline
\end{tabular}


During 8.5 5.6 ka BP, enjoying a warm and humid climate, superior hydrothermal conditions, high utilization of natural resources and fine living environment, the Neolithic Culture gradually developed. In the Houli Culture stage, hunting and gathering remained the important economic means and humans began to settle down; at the same time, simple millet agriculture emerged. In the early and middle period of Dawenkou Culture, the climate was still warm and humid. With the development of society, the population has increased substantially. The area of settlements expanded, and the proportion of agricultural economy increased. During that period, the number and types of production tools increased. Simultaneously, kiln holes and ceramic wares that were used to store grain have been invented, reflecting the rapid development of agriculture. However, the sites of this period are located on the relatively high elevations of the alluvial platform and alluvial plain. Because of the not fully discharged sea water and warm-humid climate, the study area of the western low-lying alluvial plain and coastal plain often experienced severe flood disasters. Besides, with the harsh environment, it was unsuitable for human settlement.

During 5.6 4.0 ka BP, a series of short cooling events occurred, and the degree of wetness decreased slightly, but the overall climate remained relatively mild, which created the conditions for the development of agriculture and human settlement. Through the evidence of harvesting tools and small-scale rice production found in archaeology, it can be seen that the production tools have been greatly improved.. Due to reduced precipitation, the climate was characteristically dry, sea water had withdrawn from the area, the natural environment of the western region of the study area had improved, and human activity appeared. During the late Dawenkou Culture period, the settlement sites became gradually distributed in low-lying areas, in lesser proportion. Regarding the Longshan Culture period, the number and density of archeological sites in the western region increased significantly, and agricultural production also showed great progress. Obviously, the ancient people exhibited better environment adaptability.

At approximately $4.0 \mathrm{ka} \mathrm{BP}$, the climate abruptly changed and the temperature dropped significantly. With the decrease of precipitation, the climate was dry and the environment was unsuitable for human habitation. Accordingly, the Longshan culture suddenly declined. The Yueshi culture appeared later,, but the number of archeological sites decreased dramatically, and site areas declined, while the density was also greatly reduced. After 4.0 ka BP, the climate entered the climate fluctuation period, which was accompanied by climate instability, frequent disasters, and poor environmental conditions, resulting in the decline of culture.

\section{Site distribution and seawater intrusion}

On the south coast of the Laizhou Bay area, the Holocene sea transgression started from 8.0 7.0 $\mathrm{ka} \mathrm{BP}(\mathrm{He}, 2004)$, and the climate in that period had entered the warm period. With the increase in temperature, the rising water continues to promote the submergence of land, forming a large area of wetlands and waters as well as limiting human activities. There are fewer Houli Cultural archeological sites in this area, which are distributed at elevations above $10 \mathrm{~m}$. Compared with other cultural regions in Shandong Province, settlement sites of the Beixin culture are lacking. Because of the sea transgression, some archeological sites may be submerged.

According to the analysis of Figure $6 e$ and Table 3, an elevation of $29 \mathrm{~m}$ is a special spatial boundary, and there are almost no settlements in areas with elevations above $29 \mathrm{~m}$. The formation of this boundary line is closely related to the transgression during 
the Middle Holocene, especially the invasion of the Huanghua transgression. During 8.5 2.5 ka BP, the Huanghua transgression occurred in the plain on the south coast of the Laizhou Bay, and its boundary line extends from Niutou township in the western part of the area to Houzhen-Nancun-Guti-Xiadian in the east and to the front line of Pingduxin river town (Han et al., 1999). To the north of the line, there is a marine plain, which is mainly comprised of silt, muddy silt, muddy marine and coastal sediments, and the distribution of archeological sites almost extended south of the marine plain (south of the Huanghua transgression line). Subsequently, the sea water gradually retreated, and the sea level decreased, while the activities of the ancients gradually expanded to the lower altitudes.

To approximately $6.0 \mathrm{ka} \mathrm{BP}$, because of the Huanghua transgression, the sea level reached its peak (much higher approximately 1-2 m than the modern sea level) and the invasion of sea water forced the ancients to turn to high altitude areas so as to adapt to the changes in the environment (Zhang et al., 2003). The Dawenkou culture is a good indicator of the transgression. The archeological sites are mainly distributed at 10-39 m elevations on the terrace and the alluvial plain to resist disasters from floods. For the low elevation area, there were more stagnant water phenomena, which affected the normal life of the ancients, and were nonconducive to the development of ancient production. Therefore, for the Houli Culture until the middle of the Dawenkou Culture, no archeological sites exist in the 0-9 m low altitude area. During the times of the late Dawenkou culture, seawater began to recede and there was a brief period of cooling, but overall showed warm and humid characteristics suitable for human habitation, and archeological sites at low elevations of 0-9 m began to emerge gradually, while the proportion of which, $7.4 \%$, is relatively small.

After $6.0 \mathrm{ka}$ BP, seawater gradually receded northwards, and the sea level decreased. After the sea retreated, the ancient people's activity range gradually expanded to low altitudes. At the Longshan Culture stage, sea water had basically withdrawn from the area. The climate became dry, and the sea level declining, archeological sites in lowlying areas without ancient settlements in early phases began to gradually appear. It can be seen from the elevation distribution map of Longshan culture site that in the low elevation area of 0-9 m, the number of archeological sites increased obviously, and the proportion increased from $7.4 \%$ in the previous period to $16.8 \%$. At the same time, the district found the salt manufacturing site in the Longshan period (Guo Jingzi site), which is located at a low altitude $(3 \mathrm{~m})$ near Shouguang city, as a result of the recession in seawater, and the salt-making raw materials used to make salt are very rich, which is conducive to the development of a salt industry according to local conditions (Yan, 2015).

\section{Site distribution with respect to ancient lakes and the ancient channel}

The southern coast of Laizhou Bay has historically formed lakes due to seawater intrusion and river diversion, for example, Heizhong Lake and Judian Lake (Fig. 7). On the alluvial plain, which is far from the Xiaoqing River and at a lower elevation, the Dawenkou Culture period archeological sites emerged with a new distribution type, and these archeological sites are located on the southwestern shore of Lake Judian. Up to the Longshan Culture period, the number of settlements in the region increased significantly, and were mainly concentrated on the west coast of the lake area, which showed a circular feature. In 1973, the Chinese Academy of Sciences Institute of Archeology found Lujiakou sites near Biehua lake coast of Lujiakou village, which 
belongs to the Dawenkou Culture and Longshan Culturecoast. The $4.0 \mathrm{ka}$ BP cooling event reduced the number of Longshan Culture archeological sites, and afterwards the development of Yueshi culture in the lake area also has a settlement site distribution with a proportion of $36.3 \%$. The distribution of the location is unchanged. From the beginning of Dawenkou Culture, the proportion of agricultural economy gradually increased, and the ancient lake provided water and food, which could also be induced by irrigation and fisheries development, improving the quality of life and promoting the progress of human society.

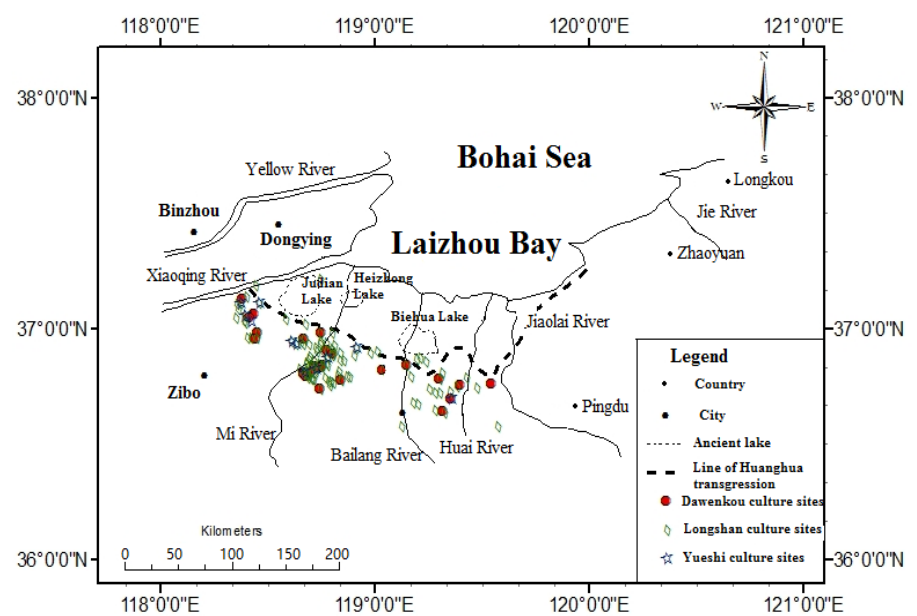

Figure 7. The relationship between settlement sites and Huanghua transgression

There are 25 ancient rivers on the south coast of Laizhou Bay, six of which were formed in the Middle Holocene period, and all of the rivers are located to the west of the river. One of the main river channels has a ${ }^{14} \mathrm{C}$ date of $7.080 \pm 96$ cal.ka $\mathrm{BP}$, indicating that the ancient river has existed for the past 7 thousand years. Agriculture had begun to appear in the HouLi Culture period, but gathering and hunting continued to constitute a major economic mode. The western part of the Bianxianwangxi site was close to the third ancient river, and with its adequate water resources and convenient fishing and hunting conditions, it became a suitable place to live. The Huanghua transgression induced sea level rise and river diversion, and the river then moved eastward. In that period, the archeological sites were mainly located at the west coast of Mi river. Compared with the Wangxi line sites of the Houli culture period, the position of the site moved relatively eastward. Towards the end of the Mid-Holocene, the sea water gradually retreated from the north, and ancient rivers moved westward. Therefore, the archeological sites of the Longshan Culture period are mainly concentrated in the Mi river, reflecting the characteristics of the ancient people living near the river.

\section{Conclusion}

Archeological studies have identified 141 Neolithic cultural sites on the south coast of Laizhou Bay, with a sequence of Houli, Dawenkou, Longshan and Yueshi. Using GIS combined with archeological and geographic data, this paper has presented the spatial-temporal distribution of the Neolithic sites in the study area. Temporally, the total number and frequency of occurrence of archeological sites throughout the 
Neolithic Age show an early descending and later ascending curve. From the elevation point of view, the four periods of archeological sites are almost all located in the alluvial plain area below $29 \mathrm{~m}$. Moreover, the formation and development of seawater intrusion, the ancient lake and the ancient river channel all influenced the distribution of the settlement sites; at the same time, human beings have gradually adapted to the environment as it changed, and they utilized resources to develop and progressed according to local conditions. Comparative analysis revealed that the close correlation of the Holocene climate change and environmental evolution with the Neolithic cultural succession indicated that ameliorated conditions generally promoted primitive cultural development, while degeneration coincided with cultural transition or interruption.

Acknowledgements. We would like to express our sincere appreciation to the anonymous reviewers for their suggestions. The work was supported by the special program for the National Natural Science Foundation of China (41471160).

\section{REFERENCES}

[1] An, C. B., Dong, W., Li, H., Zhang, P. Y., Zhao, Y. T., Zhao, X. Y., Yu, S. Y. (2015): Variability of the stable carbon isotope ratio in modern and archaeological millets: evidence from northern China. - Journal of Archaeological Science 53: 316-322.

[2] Andersen, K. K., Azuma, N., Barnola, J. M., Bigler, M., Biscaye, P. (2004): Highresolution record of Northern Hemisphere climate extending into the last interglacial period. - Nature 431: 147-151.

[3] Chen, G. Q. (2013): Study on the Mechanism and Early Warning Evaluation of Seawater Intrusion in Laizhou Bay Area. - East China Normal University, Shanghai.

[4] Contreras, D., Guiot, J., Suarez, R., Kirman, A. (2018): Reaching the human scale: A spatial and temporal downscaling approach to the archaeological implications of paleoclimate data. - Journal of Archaeological Science 93: 54-67.

[5] Dai, L., Balasse, M., Yuan, J., Zhao, C., Hu, Y., Vigne, J. D. (2016): Cattle and sheep raising and millet growing in the Longshan age in central China: stable isotope investigation at the Xinzhai site. - Quaternary International 426: 145-157.

[6] Demján, D., Dreslerová, D. (2016): Modelling distribution of archaeological settlement evidence based on heterogeneous spatial and temporal data. - Journal of Archaeological Science 69: 100-109.

[7] Dong, G., Jia, X., Elston, R., Chen, F., Li, S., Wang, L. (2013): Spatial and temporal variety of prehistoric human settlement and its influencing factors in the upper Yellow River valley, Qinghai province, China. - Journal of Archaeological Science 40(5): 25382546.

[8] Dykoski, C. A., Edwards, R. L., Cheng, H., Yuan, D., Cai, Y., Zhang, M., et al. (2005): A high-resolution, absolute-dated Holocene and deglacial Asian monsoon record from Dongge cave, China. - Earth \& Planetary Science Letters 233(1): 71-86.

[9] Goude, G., Fontugne, M. (2016): Carbon and nitrogen isotopic variability in bone collagen during the Neolithic period: influence of environmental factors and diet. Journal of Archaeological Science 70: 117-131.

[10] Guo, Y., Mo, D., Mao, L., Wang, S., Li., S. C. (2013): The relationship between settlements distribution and environmental changes from the Neolithic to Shang-Zhou periods in north Shandong province. - Acta Geographica Sinica 68(4): 559-570.

[11] Guo, Y., Mo, D., Mao, L., Jin, Y., Guo, W., Mudie, P. J. (2014): Settlement distribution and its relationship with environmental changes from the Paleolithic to Shang-Zhou period in Liyang plain, China. - Quaternary International 321(2): 29-36. 
[12] Han, M., Zhang, L. N. (2005): Sedimentary analysis and environmental evolvement of Judian lake in the south coastal plain of Laizhou Bay. - Scientia Geographica Sinica 25(6): 678-682.

[13] Han, M., Li, D. G., Zhao, M. H. (1999): Study on the paleo-river course on the southern coast of Laizhou Bay. - Scientia Geographica Sinica 19(5): 451-456.

[14] Han, M., Zhang, L. N. (2005): Sedimentary analysis and environmental evolvement of Judian lake in the south coastal plain of Laizhou Bay. - Scientia Geographica Sinica 25(6): 678-682.

[15] Han, R. (1985): Lujiakou Neolithic sites. - Journal of Archaeological 3: 313-351.

[16] Han, Y. S., Wu, H. F. (1982): The origin of underground brines in the coastal plain of Laizhou Bay. - Geological Review 28(2): 126-130.

[17] He, D. L. (2004): Shandong Neolithic environmental archaeology research. - Oriental Museum 2: 26-40.

[18] Jin, G. Y. (2000): The Qianbuxia Site Plant Silicate Body Analysis Report. - Science Press, Beijing.

[19] Karakasidou, A. (2005): The archaeology of global change: the impact of humans on their environment. - Choice: Current Reviews for Academic Libraries 42(5): 894.

[20] Kong, Q. S. (1989): GuangRao Five Village in Dawenkou Cultural Sites Animal Remains. - Shandong University Press, Jinan.

[21] Kong, Q. S. (2000): The Qianbuxia Site Excavation Report. - Science Press, Beijing.

[22] Kuper, R., Kröpelin, S. (2006): Climate-controlled Holocene occupation in the Sahara: motor of Africa's evolution. - Science 313(5788): 803-807.

[23] Li, D. G., Guo, Y. S., Jiang, A. X. (1996): Preliminary study of the Holocene sea transgression and paleo-geo-environmental differences on the southern/northern coast of Shandong Peninsula. - Acta Oceanologica Sinica 4(18): 63-71.

[24] Li, R., Carter, J. A., Xie, S., Zou, S., Gu, Y., Zhu, J. (2010): Phytoliths and microcharcoal at Jinluojia archeological site in middle reaches of Yangtze River indicative of paleoclimate and human activity during the last 3000 years. - Journal of Archaeological Science 37(1): 124-132.

[25] Li, Z. G., Wang, J. G., Liu, G. Q. (2002): The excavation of the Fujia site of Guangrao country of Shandong. - Archaeological 9: 36-44.

[26] Liu., E. F., Zhang, Z. L., Shen, J. (2004): Spore-pollen records of environmental change on the south coast plain of Laizhou bay since the late Pleistocene. - Journal of Palaeogeography 6(1): 78-84.

[27] Lyndsay, M. D., Steven, G. D., Ted, G. (2018): Deposition and pedogenesis of periglacial sediments and buried soils at the Serpentine Hot Springs archaeological site, Seward Peninsula, AK. - Catena 170: 204-233.

[28] Mayke, W., Pavel, T., Dominic, H., Andreas, F., Richard, E., Chen, X. C., Christian, L. (2013): Mapping of the spatial and temporal distribution of archaeological sites of northern China during the Neolithic and Bronze Age. - Quaternary International 291: 344-357.

[29] Spencer, C., Bevan, A. (2018): Settlement location models, archaeological survey data and social change in Bronze Age Crete. - Journal of Anthropological Archaeology 52: 71-86.

[30] Stanley, D. J., Galili, E. (1996): Sediment dispersal along northern Israel coast during the early Holocene: geological and archaeological evidence. - Marine Geology 130(1): 1117.

[31] Tan, Z., Han, Y., Cao, J., Huang, C. C., An, Z. (2015): Holocene wildfire history and human activity from high-resolution charcoal and elemental black carbon records in the Guanzhong basin of the loess plateau, China. - Quaternary Science Reviews 109: 76-87.

[32] Wang, S. G., Ning, Y. T. (2003): The prospecting report in Houli culture settlements in Shandong Zhangqiu XiaoJing mountain. - Huaxia Archaeology 3: 3-11. 
[33] Wang, X., Mo, D., Li, C., Yu, S. Y., Xue, B., Liu, B. (2017): Environmental changes and human activities at a fortified site of the Liangzhu culture in Eastern China: evidence from pollen and charcoal records. - Quaternary International. DOI: 10.1016/j.quaint.2017.05.001.

[34] Yan, S. D. (2015): Salt-making remains of the Longshan age found at the south coast of Laizhou Bay. - Archaeology 2015(12): 106-114.

[35] Yang, S., Li, J., Mao, L., Liu, K. B., Gao, M., Ye, S. (2016): Assessing pollen distribution patterns and provenance based on palynological investigation on surface sediments from Laizhou Bay, China: an aid to palaeoecological interpretation. - Palaeogeography Palaeoclimatology Palaeoecology 457: 209-220.

[36] Yao, T. D., Shi, Y. F. (1992): Climate and Environment in Megathermal Period of Holocene in China. - China Ocean Press, Beijing.

[37] Zhang, W. Y., Han, M., Li, Y. H. (2003): Study on the Cause of Death of Ancient Lakes on the South coast Plain of Laizhou Bay, Shandong Province. - Paleogeographic Bulletin 5(2): 224-231.

[38] Zheng, H. B., Zhou, Y. S., Yang, Q., Hu, Z. J., Ling, G. J., Zhang, J. Z. (2018): Spatial and temporal distribution of Neolithic sites in coastal China: sea level changes, geomorphic evolution and human adaption. - Science China Earth Sciences 61(2): 1-11. 